\title{
KAJIAN KESIAPAN KOMPETENSI GURU BAHASA INGGRIS SMP UNTUK MENDUKUNG IMPLEMENTASI KURIKULUM 2013 (K-13)
}

\author{
STUDY OF THE COMPETENCE'S READINESS OF ENGLISH TEACHER \\ AT JUNIOR SECONDARY SCHOOL TO SUPPORT THE IMPLEMENTATION \\ OF CURRICULUM 2013 (K-13)
}

\author{
Simon Sili Sabon \\ Peneliti pada Pusat Penelitian Kebijakan Pendidikan dan Kebudayaan, Balitbang, \\ Kemendikbud \\ Jalan Jenderal Sudirman-Senayan, Jakarta \\ e-mail:simonsilisabon@yahoo.com
}

Diterima: 8 Mei 2017; dikembalikan untuk direvisi: 5 Juni 2017; disetujui: 14 Juli 2017

\begin{abstract}
ABSTRAK
Tujuan kajian ini adalah memetakan kompetensi pedagogik dan profesional guru Bahasa Inggris SMP yang dapat menjadi masukan bagi pembuat kebijakan dalam merancang pendidikan dan pelatihan bagi guru yang mengajar mata pelajaran ini. Untuk mencapainya kajian ini memetakan kompetensi guru berdasarkan capaian guru untuk setiap indikator kompetensi pedagogik dan profesional yang telah diteskan dalam Uji Kompetensi Guru (UKG). Pendekatan kajian adalah kuantitatif. Data yang digunakan dalam penelitian ini adalah data sekunder tentang nilai UKG yang diperoleh dari Direktorat Jenderal Guru dan Tenaga Kependidikan (Ditjen GTK) Kementerian Pendidikan dan Kebudayaan (Kemendikbud). Data dianalisis dengan teknik statistik deskriptif menggunakan tabel frekuensi. Kajian menyimpulkan bahwa hasil UKG guru Bahasa Inggris SMP rendah karena rata-rata nasionalnya hanya 56,02 dalam skala 100, sehingga menjadi faktor yang dapat menghambat implementasi K-13. Sedangkan analisis UKG per indikator penentu kompetensi menunjukkan bahwa hanya 17 persen indikator kompetensi pedagogik dan 32 persen indikator kompetensi profesional yang dikuasai oleh guru, dengan kriteria penguasaan indikator adalah 75 persen peserta ujian menjawab benar untuk indikator kompetensi tersebut.
\end{abstract}

Kata kunci: kompetensi guru, uji kompetensi guru, implementasi kurikulum.

\begin{abstract}
The purpose of this study is to map the pedagogical and professional competence of English teachers at unior secondary school that can be used as an input for policy makers in designing education and training for English teachers. To achieve this purpose the study will map the competence of teachers based on performance test of teachers for each indicator of pedagogical and professional competence. The approach of the study is quantitative. Data used in this study is the secondary data about the result of the test of teacher's competences done by The Directorate General of Teachers and Education Personnel Ministry of Education and Culture. The data will be analized descriptively using table frequencies. The study concludes that the results of teachers' competence test for the English teachers is low because the mean value of the test is just 56,02 on a scale of 100. This result can become a factor that
\end{abstract}


could impede the implementation of $K-13$. While the analysis of the test for each determining indicator of competence shows that only 17 percent of pedagogical indicators and 32 percent of professional indicators is mastered by the teachers, with the mastery criterion indicator is 75 percent of examinees answered the questions for that indicator correctly.

Keywords: teacher's competence, test of teachers 'competence, curriculum implementation

\section{PENDAHULUAN}

Profesionalisme guru merupakan salah satu syarat utama mewujudkan pendidikan bermutu. Oleh karena itu, pemerintah telah mengupayakan langkah-langkah strategis untuk meningkatkan profesionalisme guruguru di tanah air. Menyadari begitu pentingnya peran guru, Syahbani (2013) menulis bahwa Presiden Republik Indonesia saat itu, Susilo Bambang Yudhoyono pada peringatan Hari Guru Nasional XI tahun 2004 mencanangkan Jabatan Guru sebagai Profesi. Pencanangan itu diharapkan menjadi tonggak kebangkitan guru untuk senantiasa terus meningkatkan profesionalismenya, dan sebagai upaya agar jabatan sebagai guru menjadi suatu profesi yang mempunyai daya tarik tersendiri bagi putra-putri terbaik negeri ini. Jadi, melalui pencanangan ini diharapkan status sosial guru akan meningkat secara signifikan dan tidak lagi hanya dilirik oleh mereka yang kepepet mencari kerja. Dan sejak pencanangan itu pula, gairah untuk segera menetapkan undang-undang profesi guru dan dosen berikut dengan berbagai perangkat pendukungnya, menjadi semakin kuat. Eksistensi guru tersebut kemudian dikukuhkan dalam Undang-Undang Republik Indonesia (RI) Nomor 14 tahun 2005 tentang Guru dan Dosen (UUGD).

Undang-Undang RI Nomor 20 Tahun 2003 tentang Sistem Pendidikan Nasional, UndangUndang RI Nomor 14 Tahun 2005 tentang Guru dan Dosen, Peraturan Pemerintah
Nomor 74 Tahun 2008 tentang Guru, dan Peraturan Pemerintah Nomor 19 tahun 2005 tentang Standar Nasional Pendidikan menyatakan bahwa guru merupakan pendidik profesional. Guru dipersyaratkan memiliki kualifikasi akademik minimal S1/D-IV yang relevan atau linear dengan mata pelajaran yang diajarkannya, misalnya guru Bahasa Inggris harus memiliki latar belakang pendidikan Bahasa Inggris. Selain itu guru dituntut memiliki empat kompetensi sebagai agen pembelajaran yaitu profesional, pedagogik, sosial dan kepribadian.

Pada akhir masa jabatannya, Mendikbud M. Nuh mengganti Kurikulum Tingkat Satuan Pendidikan (KTSP) atau Kurikulum 2006 menjadi Kurikulum 2013 (K-13), dengan menerbitkan peraturan baru tentang implementasi kurikulum yang dituangkan dalam Peraturan Menteri Pendidikan dan Kebudayaan Nomor 81A Tahun 2013.

Namun demikian dengan pergantian Menteri Pendidikan dan Kebudayaan pada akhir 2014, Mendikbud yang baru menangguhkan implementasi K-13, dengan menerbitkan SK Pemberhentian Pelaksanaan K-13 Nomor : 179342/MPK/KR/2014 tertanggal 5 Desember 2014, namun demikian, kajian ini niscaya dapat dimanfaatkan dalam mempersiapkan implementasi K-13 di masa yang akan datang. Cepat atau lambat K-13 akan diimplementasikan oleh seluruh sekolah, karena sekolah-sekolah 
percontohan yang menjadi tempat ujicoba pelaksanaan K-13 sejak tahun pelajaran 2013 masih tetap menerapkan K-13. Selanjutnya Mendikbud menargetkan bahwa K-13 akan diimplementasikan secara penuh atau serentak pada 2018, sebagaimana disampaikan oleh Wibowo (2015) yang menyatakan meskipun saat ini Kurikulum 2013 dihentikan dan sedang dievaluasi oleh pemerintah, namun setelah proses evaluasi selesai sekolah akan kembali menerapkan kurikulum 2013. Kemendikbud menargetkan kurikulum 2013 akan dijalankan secara penuh atau serentak pada tahun 2018.

Yama (2013) dalam penelitiannya tentang hubungan antara kompetensi guru (kepribadian, sosial, pedagogis dan profesional) terhadap kesiapan guru dalam mengimplementasi kurikulum K-13, menemukan bahwa kompetensi guru sangat berpengaruh atau berkontribusi bagi guru dalam mempersiapkan dirinya mengimplementasikan kurikulum K-13. Dengan demikian kompetensi guru dapat meningkatkan kesiapan guru dalam mengimplementasi kurikulum K-13. Karena temuannya ini maka Yama (2013) terus menyarankan guru agar lebih meningkatkan kompetensinya khususnya pedagogik seperti dalam hal meningkatkan kemampuan dalam pembelajaran dengan memahami sifat dan perkembangan peserta didik serta metodologi mengajar agar disesuaikan dengan bahan dan perkembangan siswa serta menggunakan sistem evaluasi yang tepat.

Terkait implementasi kurikulum, Patimah (2016) menulis bahwa untuk ini diperlukan seseorang yang berperan sebagai pelaksananya. Menurutnya guru merupakan faktor terpenting dalam implementasi kurikulum karena guru merupakan pelaksana kurikulum. Karena itu guru dituntut memiliki kemampuan untuk mengimplementasikannya, tanpa itu kurikulum tidak akan bermakna sebagai alat pendidikan, dan sebaliknya pembelajaran tidak akan efektif tanpa kurikulum sebagai pedoman. Dengan demikian guru menempati posisi kunci dalam implementasi kurikulum.

Terkait hasil penelitian Yama (2013) dan pendapat Patimah (2016) ini ditarik kesimpulan bahwa seorang guru yang kompeten diyakini akan mudah menyesuaikan diri dengan perubahan-perubahan yang mengarah pada peningkatan mutu pendidikan seperti melalui perubahan kurikulum. Yang menjadi pertanyaan dan sekaligus menjadi permasalahan dalam kajian ini adalah apakah guru-guru kita khususnya guru Bahasa Inggris SMP sudah cukup kompeten untuk dapat menerima dan menerapkan perubahan kurikulum. Pertanyaan ini timbul antara lain karena adanya hasil penelitian Sarwanto (2012) yang menemukan bahwa hasil UKG 2012 mengecewakan, karena rerata nilai kompetensi profesional peserta UKG 2012 hanya 44,55. Selain itu, dalam beberapa artikel di media masa diberitakan bahwa kompetensi guru kita masih sangat rendah. Salah satu contoh artikel tentang ini dimuat dalam surat kabar Poskota tertanggal 16 Maret 2012 yang ditulis oleh Rizal (2012) yang memberitakan bahwa hasil Uji Kompetensi Guru (UKG) tahun 2012 sangat rendah dan tidak memuaskan. Dari 33 provinsi hanya 8 provinsi yang mendapat nilai di atas ratarata nasional, sedangkan 25 provinsi lainnya masih di bawah nilai rata-rata nasional yaitu 42,25. Oleh karena rata-rata nilai nasional UKG hanya 42,25 dalam skala 100 ini maka 
dapat dikatakan bahwa hasil UKG tahun 2012 tidak memuaskan.

Dari hasil UKG ini juga diketahui bahwa kompetensi guru sangat terkait erat dengan kinerja guru yang diindikasikan dengan nilai Ujian Nasional (UN). Rizal (2012) dalam surat kabar Poskota memberitakan pula bahwa provinsi-provinsi yang rata-rata nilai UKG-nya di atas rata-rata nasional, nilai Ujian Nasional (UN) siswanya juga di atas rata-rata nasional. Hal ini sejalan dengan pendapat bahwa guru yang kompeten/ profesional akan lebih mudah dalam menerima dan menerapkan perubahanperubahan dalam bidang pendidikan seperti perubahan kurikulum yang bertujuan untuk meningkatkan mutu pendidikan.

Sebagaimana disebutkan sebelumnya seorang guru yang profesional harus memiliki empat kompetensi yaitu profesional, pedagogik, sosial dan kepribadian. Dari sini terlihat bahwa lingkup kajian ini sangat luas, untuk itu lingkup kajian ini dibatasi hanya pada kepemilikan dua kompetensi guru saja yaitu profesional dan pedagogik. Lingkup ini sengaja diambil karena kajian ini akan memanfaatkan data Ujian Kompetensi Guru (UKG) 2012 dan UKG hanya mengetes kedua kompetensi tersebut.

Sesuai dengan permasalahan dalam kajian yang disebutkan sebelumnya maka tujuan dari kajian ini adalah: memetakan kompetensi guru baik kompetensi pedagogik maupun kompetensi profesional yang dapat menjadi masukan bagi pembuat kebijakan dalam merancang pendidikan dan pelatihan khusus bagi guru Bahasa Inggris SMP berdasarkan capaian UKG-nya. Untuk mencapai tujuan ini maka kajian ini melakukan: "Pemetaan hasil ujian kompetensi guru berdasarkan capaian guru untuk setiap indikator kompetensi pedagogik dan profesional yang diteskan dalam UKG.

\section{KAJIAN PUSTAKA}

\section{Pengertian Kompetensi Guru}

Novauli (2015) mendefenisikan kompetensi sebagai perilaku yang rasional untuk mencapai tujuan sesuai dengan kondisi yang diharapkan. Kompetensi dalam arti luas merupakan standar kemampuan yang diperlukan untuk menggambarkan kualifikasi seseorang baik secara kualitatif maupun kuantitatif dalam melandasi pelaksanaan tugas profesional atau kemampuan teknis. Seseorang dinyatakan kompeten di bidang tertentu apabila dia menguasai kecakapan bekerja sebagai suatu keahlian selaras dengan bidangnya. Kompetensi sebagai pengetahuan, keterampilan, dan nilai-nilai dasar yang direfleksikan dalam kebiasaan berpikir dan bertindak. Kompetensi adalah spesifikasi dari pengetahuan, keterampilan, dan sikap yang dimiliki seseorang serta penerapannya di dalam pekerjaan, sesuai dengan standar kinerja yang dibutuhkan oleh lapangan.

Selanjutnya Novauli (2015) mengartikan kompetensi guru sebagai penguasaan terhadap suatu tugas (mengajar dan mendidik), keterampilan, sikap dan apresiasi yang diperlukan untuk menunjang keberhasilan proses pendidikan yang dilakukannya. Dengan demikian kompetensi guru tidak hanya berkenaan dengan kemampuan guru dalam menyajikan pelajaran di depan kelas, melainkan termasuk keterampilan guru dalam mendidik dan menanamkan sikap yang baik kepada anak didik. Jadi kompetensi guru adalah kelayakan untuk menjalankan tugas, kemampuan sebagai suatu faktor 
penting bagi guru, oleh karena itu kualitas dan produktivitas kerja guru harus mampu memperlihatkan perbuatan profesional yang bermutu.

\section{Pengertian Kurikulum dan Perlunya Perubahan Kurikulum}

Qomariyah (2014) mengungkapkan bahwa kurikulum sebagai suatu hal yang esensial dalam suatu penyelenggaraan pendidikan. Secara sederhana, kurikulum dapat dimengerti sebagai suatu kumpulan atau daftar pelajaran yang akan diajarkan kepada peserta didik komplit dengan cara pemberian nilai pencapaian belajar dalam kurun waktu tertentu. Kurikulum harus mampu mengakomodasi kebutuhan peserta didik yang berbeda secara individual, baik ditinjau dari segi waktu maupun kemampuan belajar. Kurikulum lantas didefinisikan sebagai suatu perangkat yang dijadikan acuan dalam mengembangkan suatu proses pembelajaran yang berisi kegiatan-kegiatan siswa yang akan dapat diusahakan untuk mencapai suatu tujuan pembelajaran khususnya dan tujuan pendidikan secara umum.

Lebih lanjut disampaikan Qomariyah (2014) bahwa perubahan kurikulum dari waktu ke waktu bukan tanpa alasan dan landasan yang jelas, sebab perubahan ini disemangati oleh keinginan untuk terus memperbaiki, mengembangkan, dan meningkatkan kualitas sistem pendidikan nasional. Persekolahan sebagai ujung tombak dalam implementasi kurikulum dituntut untuk memahami dan mengaplikasikannya secara optimal dan penuh kesungguhan, sebab mutu penyelenggaraan proses pendidikan salah satunya dilihat dari hal tersebut. Namun di lapangan, perubahan kurikulum sering kali menimbulkan persoalan baru, sehingga pada tahap implementasinya memiliki kendala teknis, sehingga sekolah sebagai penyelenggara proses pendidikan formal sedikit banyaknya pada tahap awal ini membutuhkan energi yang besar hanya untuk mengetahui dan memahami isi dan tujuan kurikulum baru. Dalam teknik pelaksanaannya pun sedikit terkendala karena diperlukan adaptasi terhadap perubahan atas kurikulum terdahulu yang sudah biasa diterapkannya.

\section{Hakikat Profesi dan Kompetensi Guru}

Dalam pengertian kompetensi guru menurut Novauli (2015) terkandung suatu konsep bahwa guru profesional dalam bekerja melaksanakan fungsi dan tujuan sekolah harus memiliki kompetensi-kompetensi yang dituntut agar guru mampu melaksanakan tugasnya dengan sebaik-baiknya. Perbedaan antara profesi guru dengan profesi lainnya terletak dalam tugas dan tanggung jawab. Tugas dan tanggung jawab tersebut erat kaitannya dengan kemampuan yang disyaratkan untuk memangku profesi tersebut. Oleh karena itu setiap guru pada suatu lembaga pendidikan harus memiliki berbagai ketentuan atau syarat-syarat untuk menjadi seorang guru. Salah satu syarat tersebut adalah memiliki kompetensi (kemampuan) untuk melaksanakan kegiatan pengajaran dan pendidikan dengan optimal. Syarat lainnya adalah guru harus sehat mental dan fisik, serta memiliki ijazah keguruan yang dikeluarkan oleh lembaga pendidikan keguruan.

Guru profesional bukanlah hanya untuk satu kompetensi saja yaitu kompetensi profesional, tetapi guru profesional harus mampu memiliki empat kompetensi 
sekaligus sebagaimana yang diamanatkan dalam Undang-Undang Nomor 14 Tahun 2005 tentang Guru dan Dosen dan Peraturan Pemerintah Nomor 19 Tahun 2005 tentang Standar Nasional Pendidikan. Dalam peraturan perundang-uandangan tersebut diamanatkan agar guru professional harus memahami, menguasai, dan terampil menggunakan sumber-sumber belajar baru dan menguasai kompetensi pedagogik, kompetensi kepribadian, kompetensi profesional, dan kompetensi sosial sebagai bagian dari kemampuan guru. Dengan demikian, kompetensi yang dimiliki oleh setiap guru akan menunjukkan kualitas guru yang sebenarnya, kompetensi tersebut akan terwujud dalam bentuk penguasaan pengetahuan, keterampilan maupun sikap profesional dalam menjalankan tugas dan fungsi sebagai guru.

Hubungan antara kompetensi dengan profesionalisme guru dapat dilihat pada Undang-Undang Nomor 14 Tahun 2005 tentang Guru dan Dosen yang mengamanatkan bahwa profesi guru merupakan bidang pekerjaan khusus yang dilaksanakan berdasarkan standar kompetensi sesuai bidang tugasnya dan pelaksanaan pengembangan keprofesian berkelanjutan sepanjang hayat. Disebutkan pula bahwa dari segi hak dan kewajiban, dalam melaksanakan tugas keprofesionalan, maka guru berhak memperoleh kesempatan untuk meningkatkan kompetensi, memperoleh pelatihan dan pengembangan profesi dalam bidangnya.

Jadi, guru sebagai suatu profesi, merupakan suatu jabatan yang memerlukan keahlian khusus sebagai guru dan tidak dapat dilakukan oleh sembarang orang di luar bidang pendidikan. Seorang guru sebagai pengajar harus memiliki 10 prinsip-prinsip mengajar sebagaimana yang disampaikan oleh Slameto (2010) yakni: (i) perhatian: di dalam mengajar guru harus dapat membangkitkan perhatian siswa kepada pelajaran yang diberikan oleh guru, (ii) aktivitas: dalam proses belajar mengajar, guru perlu membangkitkan aktivitas siswa dalam berpikir maupun berbuat, (iii) apersepsi: setiap guru dalam mengajar perlu menghubungkan pelajaran yang akan diberikan dengan pengetahuan yang telah dimiliki siswa, ataupun pengalamannya, (iv) peragaan: waktu guru mengajar di depan kelas, guru harus berusaha menunjukkan benda-benda yang asli. Bila mengalami kesukaran boleh menunjukkan model, gambar, benda tiruan, atau menggunakan media lainnya seperti radio, tape recorder, TV dan lain sebagainya, (v) repetisi: bila guru menjelaskan sesuatu unit pelajaran, itu perlu diulang beberapa kali, (vi) korelasi: guru dalam mengajar wajib memperhatikan dan memikirkan hubungan antar setiap mata pelajaran, (vii) konsentrasi: hubungan antar mata pelajaran bisa luas, mungkin dapat dipusatkan kepada salah satu pusat minat, sehingga siswa memperoleh pengetahuan secara luas tetapi mendalam, (viii) sosialisasi: dalam perkembangannya siswa perlu bergaul dengan teman lainnya. Siswa di samping sebagai individu juga mempunyai sisi sosial yang perlu dikembangkan, (ix) individualisasi: siswa merupakan makhluk individu yang unik, dimana masingmasing mempunyai perbedaan khas, seperti perbedaan inteligensi, minat bakat, hobi, tingkah laku, watak maupun sikapnya, dan (x) evaluasi: semua kegiatan mengajar belajar perlu dievaluasi. Evaluasi dapat memberi 
motivasi bagi guru maupun siswa.

\section{Pengertian Guru Profesional}

Ciptasari (2009) mendefenisikan guru profesional sebagai guru yang melaksanakan tugas keguruan dengan kemampuan tinggi (profisiensi) sebagai sumber kehidupan. Jadi pengertian guru profesional adalah seseorang yang memiliki kemampuan dan keahlian khusus dalam bidang keguruan sehingga dia mampu melakukan tugas dan fungsinya sebagai guru dengan kemampuan maksimal. Atau dengan kata lain guru profesional adalah orang yang terdidik dan terlatih dengan baik serta memiliki pengalaman yang kaya di bidangnya. Yang dimaksud dengan terdidik dan terlatih bukan hanya memperoleh pendidikan formal tetapi juga harus menguasai berbagai strategi atau tekhnik di dalam kegiatan belajar mengajar serta menguasai landasan-landasan kependidikan seperti yang tercantum dalam kompetensi. Kompetensi profesional mengacu pada perbuatan yang bersifat rasional dan memiliki spesifikasi tertentu dalam melaksanakan tugas kependidikan. Guru sebagai tenaga yang profesional dituntut untuk memiliki kemampuan sesuai dengan bidangnya.

Sementara itu dalam peraturan Menteri Pendidikan Nasional Nomor 16 Tahun 2007 disebutkan bahwa seorang guru profesional harus memiliki 4 kompetensi yaitu: (i) kompetensi pedagogik: kompetensi ini terkait kemampuan seorang guru dalam memahami karakteristik atau kemampuan yang dimiliki oleh murid melalui berbagai cara. Cara yang utama yaitu dengan memahami murid melalui perkembangan kognitif murid, merancang pembelajaran dan pelaksanaan pembelajaran serta evaluasi hasil belajar sekaligus pengembangan murid, (ii) kompetensi kepribadian: kompetensi kepribadian ini adalah salah satu kemampuan personal yang harus dimiliki oleh guru profesional dengan cara mencerminkan kepribadian yang baik pada diri sendiri, bersikap bijaksana serta arif, bersikap dewasa dan berwibawa serta mempunyai akhlak mulia untuk menjadi suri teladan yang baik, (iii) kompetensi profesional: kompetensi profesional adalah salah satu unsur yang harus dimiliki oleh guru yaitu dengan cara menguasai materi pembelajaran secara luas dan mendalam, dan (iv) kompetensi sosial: kompetensi sosial adalah salah satu kompetensi yang harus dimiliki oleh seorang guru melalui cara yang baik dalam berkomunikasi dengan murid dan seluruh tenaga kependidikan atau juga dengan orang tua/wali peserta didik dan masyarakat sekitar.

\section{Hubungan antara Kompetensi Guru dengan Prestasi Belajar Siswa}

Ermawati (2015) menulis bahwa keberhasilan tujuan pendidikan tidak dapat terwujud apabila tidak didukung oleh tenaga pendidik yang profesional yaitu guru. Guru adalah figur inspirator dan motivator murid dalam mengukir masa depannya. Proses pembelajaran merupakan proses guru dan siswa melakukan interaksi secara bersamasama, pada waktu yang sudah diatur oleh sekolah yang terdiri dari perencanaan, pelaksanaan dan evaluasi. Kelancaran proses pembelajaran di sekolah ditentukan oleh perilaku dan sikap guru dalam mengajar. Sudah jelas sekali, bahwa guru dituntut untuk cakap dalam mewujudkan prestasi belajar siswa. Jadi sudah sangat jelas bahwa profesionalisme adalah suatu pekerjaan yang 
dalam melaksanakan tugasnya memerlukan atau menuntut keahlian. Sedangkan seorang guru adalah pendidik profesional dengan tugas utamanya mendidik, mengajar, membimbing, mengarahkan, melatih, menilai, dan mengevaluasi peserta didik pada jalur formal. Maka tugas guru akan efektif jika memiliki derajat profesionalitas tertentu yang tercermin dari kompetensi, kemahiran, kecakapan atau keterampilan yang memenuhi standar mutu.

Ermawati (2015) dalam penelitiannya menemukan bahwa terdapat hubungan yang signifikan antara kompetensi guru dengan prestasi belajar siswa. Hal tersebut dibuktikan pada nilai koefisien korelasi product moment dari nilai rxy yang besarnya 0,583 dan selanjutnya dibandingkan dengan r-tabel product moment dengan $\mathrm{N}=26$, pada taraf signifikansi $1 \%$ diperoleh nilai 0,496 . Hal ini menunjukkan bahwa tinggi rendahnya kompetensi guru berpengaruh pada prestasi belajar siswa. Dengan demikian peran guru sangat vital bagi pembentukan kepribadian, cita-cita, visi misi yang menjadi impian hidup anak didiknya di masa depan. Jika guru-guru yang berinteraksi langsung dengan murid kurang profesional, kreatif, dan produktif, maka anak didik akan lahir sebagai kader penerus bangsa yang malas, suka mengeluh dan pesimis dalam menghadapi masa depan.

\section{Peran Guru dalam Implementasi Kurikulum}

Qomariyah (2014) menulis bahwa dalam studi tentang ilmu mengajar dan kurikulum, pembahasan mengenai permasalahan yang dialami guru senantiasa mendapat tempat tersendiri dan mendapat perhatian yang sangat serius. Hal ini dikarenakan guru mengemban peran yang sangat penting dalam keberhasilan proses pendidikan. Betapa bagus dan indahnya kurikulum, keberhasilan kurikulum tersebut pada akhirnya bergantung pada masing-masing guru.

Patimah (2016) menyebutkan bahwa dalam implementasi kurikulum memerlukan seseorang yang berperan sebagai pelaksananya. Guru merupakan faktor penting dalam implementasi kurikulum karena ia merupakan pelaksana kurikulum. Karena itu guru dituntut memiliki kemampuan untuk mengimplementasikannya, tanpa itu kurikulum tidak akan bermakna sebagai alat pendidikan, dan sebaliknya pembelajaran tidak akan efektif tanpa kurikulum sebagai pedoman. Dengan demikian guru menempati posisi kunci dalam implementasi kurikulum.

Lebih lanjut Patimah (2016) merumuskan terdapat empat peran guru dalam pengembangan kurikulum yakni: (i) sebagai implementer, guru berperan untuk mengaplikasikan kurikulum yang sudah ada. Dalam pengembangan kurikulum guru dianggap sebagai tenaga teknis yang bertanggung jawab dalam mengimplementasikan berbagai ketentuan yang ada, (ii) sebagai penyelaras kurikulum dengan karakteristik dan kebutuhan siswa serta kebutuhan daerah. Guru diberikan kewenangan untuk mnyesuaikan kurikulum dengankebutuhandaerahataupunkarakteristik sekolah, (iii) sebagai pengembang kurikulum, guru memiliki kewenangan dalam mendesain sebuah kurikulum. Guru tidak hanya bisa menentukan tujuan dan isi pelajaran yang akan disampaikan, tetapi bahkan dapat menentukan strategi apa yang harus dikembangkan dan sistem evaluasi apa yang akan digunakannya. Sebagai 
pengembang kurikulum, guru sepenuhnya dapat menyusun kurikulum sesuai dengan karakteristik, misi dan visi sekolah, serta sesuai dengan pengalaman belajar yang diperlukan anak didik, dan (iv) sebagai peneliti kurikulum (curriculum researcher). Peran ini dilaksanakan sebagai bagian dari tugas profesional guru yang memiliki tanggung jawab dalam meningkatkan kinerjanya sebagai guru. Dalam peran ini guru memiliki tanggung jawab untuk menguji berbagai komponen kurikulum, misalnya menguji bahan-bahan kurikulum, menguji efektivitas program, strategi maupun model pembelajaran, termasuk mengumpulkan data tentang keberhasilan siswa mencapai target kurikulum.

Murniyati (2013) menyampaikan bahwa dalam pelaksanaan atau implementasi kurikulum, guru memegang peranan yang sangat penting/utama dalam mentransformasikan nilai-nilai yang terkandung dalam buku kurikulum sesuai dengan petunjuknya kepada siswa dalam proses belajar mengajar. Oleh karena itu, berhasil tidaknya kurikulum sangat tergantung pada peranan guru yang dapat dilakukan dalam pengembangan kurikulum yakni: (i) guru sebagai perencana pengajaran: guru harus membuat perencanaan pengajaran dan persiapan sebelum melakukan kegiatan mengajar, (ii) guru sebagai pengelola pengajaran: guru harus dapat menciptakan situasi belajar yang memungkinkan tercapainya tujuan pengajaran yang telah ditentukan, (iii) guru sebagai evaluator: artinya guru melakukan pengukuran untuk mengetahui apakah anak telah mencapai hasil belajar seperti yang diharapkan. Disampaikan pula bahwa dalam melaksanakan peran- peran di atas guru dituntut untuk mampu mengembangkan sikap keprofesionalannya dalam melaksanakan tugas dan tanggung jawab pendidikan. Guru profesional dalam hubungan ini adalah guru yang memiliki keahlian khusus, artinya guru harus mempunyai kompetensi atau kemampuan dasar sebagai syarat untuk memangku profesi tersebut.

\section{Upaya Peningkatan Kompetensi Guru}

Ngasbun (2012) mengungkapkan bahwa upaya mempersiapkan guru agar memiliki berbagai wawasan, pengetahuan, keterampilan, dan rasa percaya diri yang tinggi untuk melaksanakan tugas dan kewajibannya sebagai pengemban tugas profesi, merupakan langkah strategis membangun mutu pendidikan. Dikatakan bahwa pengembangan atau peningkatan kemampuan profesional guru harus bertolak pada kebutuhan atau permasalahan nyata yang dihadapi oleh guru. Guru dituntut lebih dinamis dan kreatif dalam mengembangkan proses persiapan, pelaksanaan dan evaluasi pembelajaran siswa. Untuk itu guru dituntut untuk terus menerus mengembangkan kompetensinya untuk mengembangkan profesionalismenya, di samping terus berusaha menghindarkan diri dari hal-hal yang tidak sesuai dengan amanat profesinya, sehingga guru dengan kompetensi dan profesionalisme tinggi mampu memberikan pelayanan prima bagi para siswanya.

Komara (2016) dalam kajiannya menemukan bahwa pembinaan dan pengembangan profesi serta pembinaan dan pengembangan karir guru belum sepenuhnya terjamin oleh pemerintah. Padahal menurut peraturan perundang-undangan perlindungan 
profesi bagi guru merupakan bagian integral dari upaya untuk memenuhi hak-hak guru. Salah satu hak guru adalah memperoleh kesempatan untuk meningkatkan kompetensi pembelajaran untuk memperlancar tugas keprofesionalannya.

Agar pemerintah dapat melaksanakan kewajibannya untuk memberikan pelatihan kepada guru, perlu diketahui terlebih dahulu akar permasalahan yang dihadapi guru sehingga dapat dirancang pelatihan yang tepat untuk meningkatkan kompetensi guru. Selama ini banyak yang mengatakan bahwa pelatihan yang dilakukan untuk meningkatkan kompetensi guru kurang efektif, sebagaimana yang disampaikan oleh Jalmo dan Rustaman (2010) bahwa di Indonesia, peningkatan profesionalitas guru yang dilakukan melalui berbagai pelatihan hasilnya belum optimal, bahkan banyak pelatihan dapat dinilai gagal dalam meningkatkan kinerja guru di kelas. Dikatakannya bahwa pelatihan guru yang selama ini dilaksanakan melalui berbagai proyek peningkatan mutu pendidikan banyak yang tidak efektif, karena banyak pelatihan dilaksanakan hanya sekedar memenuhi tuntutan proyek.

Bertolak dari sini, untuk meningkatkan efektivitas pelatihan bagi guru maka diadakan pemetaan kompetensi guru. Pada tahun 2012 diadakan uji kompetensi guru oleh Ditjen GTK Kemendikbud yang pada tahun 2014 masih bernama Badan Pengembangan Sumber Daya Manusia Pendidikan dan Kebudayaan dan Penjaminan Mutu Pendidikan (BPSDMPK dan PMP). Uji Kompetensi Guru (UKG) dimaksudkan untuk mengetahui peta penguasaan guru pada kompetensi pedagogik dan kompetensi profesional. Peta penguasaan kompetensi guru tersebut digunakan sebagai dasar pertimbangan dalam pemberian program pembinaan dan pengembangan profesi guru (BPSDMPK dan PMP, 2012).

\section{Kerangka Berpikir Kajian}

Dari latar belakang kajian ini kemudian berdasarkan tinjauan pustaka yang ada dicoba disusun kerangka berpikir kajian sebagai berikut.

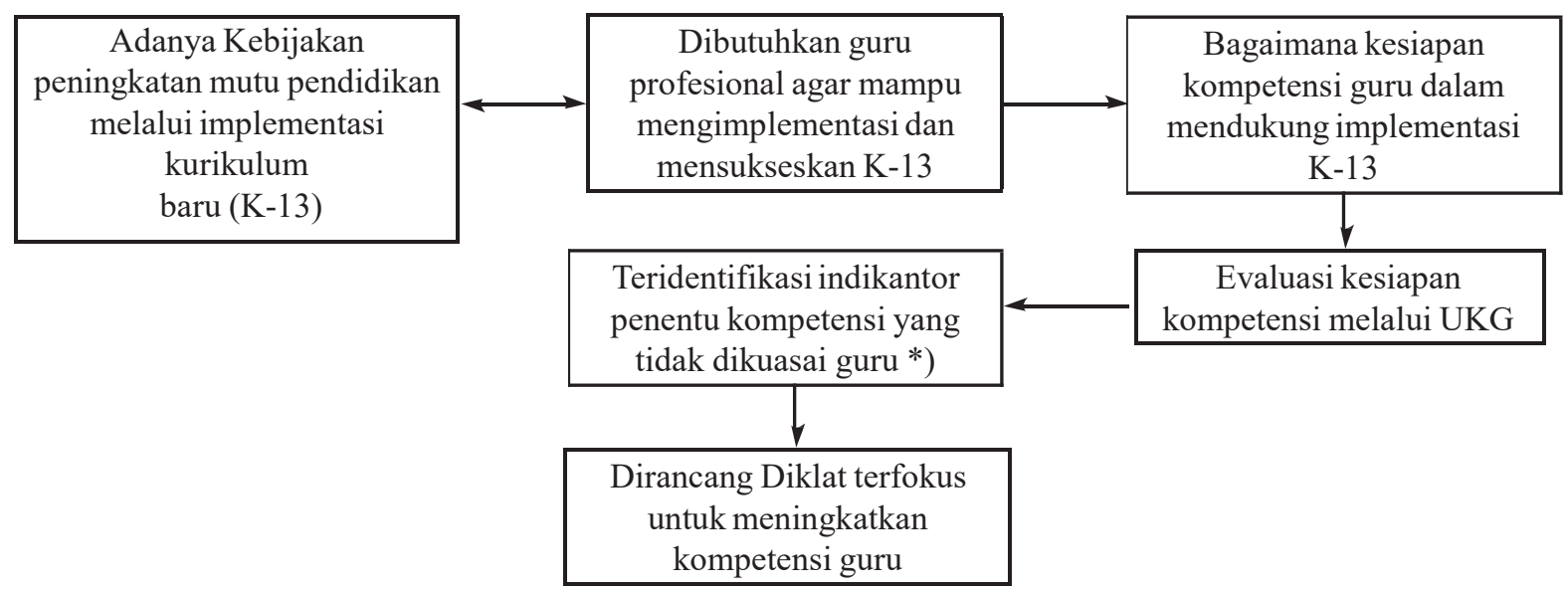

Gambar 1. Kerangka Berpikir Kajian

Catatan: *) Kriteria suatu indikator penentu kompetensi dianggap dikuasai guru apabila minimal 75 persen peserta UKG menjawab benar untuk pertanyaan terkait indikator tersebut (diadopsi dari Panduan Penyusunan Kurikulum Tingkat Satuan Pendidikan yang diterbitkan Badan Standar Nasional Pendidikan, 2006). 


\section{METODE PENELITIAN}

Pendekatan kajian ini adalah kuantatif. Sasaran populasi kajian ini adalah guru Bahasa Inggris SMP. Kajian ini tidak menetapkan sampel khusus karena seluruh data sekunder yaitu nilai Ujian Kompetensi Guru (UKG) dari setiap guru Bahasa Inggris SMP yang dites pada tahun 2012 oleh Direktorat Jenderal Guru dan Tenaga Kependidikan (Ditjen GTK) Kementerian Pendidikan dan Kebudayaan (Kemendikbud) digunakan dalam analisis data untuk kajian ini.

Data yang digunakan dalam kajian ini adalah nilai UKG guru Bahasa Inggris SMP tahun 2012. Data tersebut diperoleh dari Ditjen GTK Kemendikbud. Komposisi data tersebut terdiri atas nilai UKG untuk setiap indikator penentu kompetensi baik kompetensi pedagogik maupun kompetensi profesional. Data sekunder berupa nilai UKG 2012 dianalisis menggunakan statistik deskriptif. Rata-rata nilai UKG disajikan dalam bentuk tabel frekuensi untuk mendapatkan gambaran yang detail tentang capaian guru atas setiap indikator penentu kompetensi pedagogik dan profesional yang dites. Hal ini untuk memberikan masukan kepada pembuat kebijakan di tingkat Pusat dan daerah dalam menetapkan kebijakan pelatihan guru agar lebih fokus pada indikator penentu kompetensi yang belum tuntas pembelajarannya.

\section{HASIL DAN PEMBAHASAN}

Dalam pedoman UKG 2012 disebutkan bahwa tujuan pemerintah mengadakan UKG adalah (i) memetakan penguasaan kompetensi guru (kompetensi pedagogik dan profesional) sebagai dasar pertimbangan pelaksanaan program pembinaan dan pengembangan profesi guru dalam bentuk kegiatan pengembangan keprofesian berkelanjutan dan (ii) sebagai entry point penilaian kinerja guru dan sebagai alat kontrol pelaksanaan penilaian kinerja guru. Dalam UKG hanya 2 dari 4 kompetensi guru yang dievaluasi yaitu kompetensi profesional dan pedagogik. Kedua kompetensi ini yang dapat dievaluasi menggunakan pencil and paper test, sedangkan untuk dua kompetensi lainnya yaitu kepribadian dan sosial sulit dievaluasi dengan pencil and paper test sehingga UKG hanya meliputi kompetensi profesional dan pedagogik.

UKG tahun 2012 mengukur kompetensi dasar tentang bidang studi (subject matter) dan pedagogik dalam domain content (BPSDMPK\&PMP, Kemendikbud, 2012). Capaian kompetensi guru Bahasa Inggris SMP berdasarkan hasil UKG tahun 2012 disajikan sebagai berikut.

Pada bagian ini disajikan capaian kompetensi guru Bahasa Inggris SMP secara umum, yaitu rata-rata nilai UKG dan juga rata-rata nilai kompetensi pedagogik dan profesional, sebagaimana disajikan dalam tabel berikut. 
Tabel 1. Gambaran Kompetensi Guru SMP Bahasa Inggris Secara Umum

\begin{tabular}{|l|c|r|r|r|r|r|}
\hline \multicolumn{1}{|c|}{ Kompetensi } & $\mathrm{n}$ & Mean & Median & Std. Dev & Minimum & Maximum \\
\hline Pedagogik & 13.406 & 48,81 & 50,00 & 13,03 & 0,00 & 92,86 \\
\hline Profesional & 13.406 & 60,46 & 61,29 & 15,80 & 0,00 & 95,16 \\
\hline Nilai Akhir UKG & 13.406 & 56,84 & 57,78 & 14,09 & 0,00 & 90,00 \\
\hline
\end{tabular}

Sumber: Hasil Uji Kompetensi Guru, 2012 (diolah)

Dari tabel di atas terlihat bahwa jumlah guru SMP yang mengajar mata pelajaran Bahasa Inggris yang ikut UKG adalah sebanyak 13.406 orang. Selanjutnya terlihat bahwa dalam skala nilai 100 , rata-rata (mean) nilai UKG untuk kompetensi pedagogik adalah 48,81; sedangkan rata-rata (mean) nilai UKG untuk kompetensi profesional lebih tinggi yaitu mencapai 60,46. Namun demikian, capaian ini masih terlalu rendah. Kenyataan ini sangat memprihatinkan jika hasil tes ini dibandingkan dengan Penilaian Acuan Norma (PAN), yaitu seorang peserta ajar dinyatakan lulus jika nilainya minimal 60 dalam skala 100. Dengan PAN sebagai acuan maka sebagian besar guru-guru tidak lulus UKG karena rerata nilai akhir UKG adalah 56,84, masih di bawah ketentuan PAN yaitu minimal 60. Analisis ini masih terlalu umum, sehingga tidak bisa dibuat opsi kebijakan yang terfokus untuk meningkatkan kompetensi guru. Untuk itu perlu dilakukan analisis lebih khusus lagi agar diperoleh gambaran yang lebih jelas sehingga dapat dibuat rekomendasi kebijakan untuk meningkatkan kompetensi guru.

Kenyataan bahwa masih banyak guru tidak lulus UKG berdasarkan acuan PAN menunjukkan bahwa sudah pasti banyak indikator penentu kompetensi guru yang belum dikuasai oleh guru. Kriteria untuk menentukan penguasaan guru atas indikator kompetensi diadopsi dari panduan penyusunan Kurikulum Tingkat Satuan Pendidikan (KTSP) jenjang pendidikan dasar dan menengah yang diterbitkan Badan Standar Nasional Pendidikan (BSNP) pada 2006 dimana disebutkan kriteria ketuntasan belajar suatu indikator adalah jika minimal 75 persen peserta tes menjawab benar untuk indikator tersebut. Analisis selanjutnya adalah tentang penguasaan guru terhadap setiap indikator yang diujikan dalam UKG.

Untuk mengukur kompetensi pedagogik telah dilakukan tes penguasaan guru terhadap 24 indikator kompetensi pedagogik sedangkan untuk mengukur kompetensi profesional telah dilakukan tes penguasaan guru terhadap 59 indikator kompetensi profesional. Berikut ini disajikan dua tabel berturut-turut tentang pesentase guru yang menjawab benar untuk setiap indikator yang dites. Tabel pertama menyajikan pesentase guru yang menjawab benar untuk setiap indikator kompetensi pedagogik sedangkan tabel kedua menyajikan pesentase guru yang menjawab benar untuk setiap indikator kompetensi professional. 
Tabel 2. Penguasaan Guru Bahasa Inggris SMP terhadap setiap Indikator kompetensi pedagogik dalam UKG $2012(\mathrm{~N}=13.406)$

\begin{tabular}{|c|c|c|}
\hline No. & Indikator & $\begin{array}{l}\% \\
\text { yang jawab } \\
\text { benar }\end{array}$ \\
\hline 1. & $\begin{array}{l}\text { Diberi suatu topik pembelajaran bahasa Inggris untuk pembelajaran } \\
\text { teks tertentu, guru dapat menentukan bekal-ajar awal yang diperlukan } \\
\text { peserta didik }\end{array}$ & 7,56 \\
\hline 2. & $\begin{array}{l}\text { Diberi deskripsi kasus dalam suatu pembelajaran bahasa Inggris, guru } \\
\text { dapat menentukan rumusan judul PTK yang paling sesuai }\end{array}$ & 19,30 \\
\hline 3. & $\begin{array}{l}\text { Diberi contoh tulisan siswa yang mengandung kesalahan tertentu, } \\
\text { guru dapat menentukan kesulitan peserta didik dalam mempelajari } \\
\text { keterampilan berbahasa Inggris }\end{array}$ & 19,35 \\
\hline 4. & $\begin{array}{l}\text { Diberi suatu rumusan indikator pencapaian suatu KD atau tujuan } \\
\text { pembelajaran bahasa Inggris tertentu, guru dapat menentukan teknik } \\
\text { dan instrumen penilaian yang dikembangkan }\end{array}$ & 22,37 \\
\hline 5. & $\begin{array}{l}\text { Diberi kasus peserta didik dengan potensi tertentu dalam pembelajaran } \\
\text { bahasa Inggris, guru dapat mengidentifikasikannya dengan benar }\end{array}$ & 29,66 \\
\hline 6. & $\begin{array}{l}\text { Diberi suatu rumusan tujuan pembelajaran bahasa Inggris tertentu, } \\
\text { guru dapat menentukan pengalaman belajar yang sesuai untuk } \\
\text { mencapai tujuan tersebut }\end{array}$ & 30,82 \\
\hline 7. & $\begin{array}{l}\text { Diberikan deskripsi karakteristik pembelajar bahasa Inggris tertentu, } \\
\text { guru dapat menentukan pilihan kegiatan pembelajaran yang dapat } \\
\text { mendorong terjadinya aktualisasi potensi dan kreativitasnya }\end{array}$ & 32,74 \\
\hline 8. & $\begin{array}{l}\text { Ditanyakan karakteristik tes bahasa yang baik, guru dapat menentukan } \\
\text { pilihan ciri-ciri tes yang baik }\end{array}$ & 37,17 \\
\hline 9. & $\begin{array}{l}\text { Diberi suatu deskripsi pendekatan yang dipilih dan karakteristik } \\
\text { pembelajar bahasa Inggris, guru dapat menentukan rancangan materi } \\
\text { pembelajaran yang benar dan sesuai }\end{array}$ & 37,62 \\
\hline 10. & $\begin{array}{l}\text { Diberikan suatu rumusan KD, indikator atau tujuan pembelajaran } \\
\text { bahasa Inggris tertentu, guru dapat menentukan pendekatan, strategi, } \\
\text { metode, atau teknik pembelajaran }\end{array}$ & 44,30 \\
\hline 11. & $\begin{array}{l}\text { Diberi deskripsi suatu komponen RPP, guru dapat menentukan pilihan } \\
\text { yang menggambarkan pengembangan komponen tersebut }\end{array}$ & $\begin{array}{l}44 \\
, 68\end{array}$ \\
\hline 12. & $\begin{array}{l}\text { Diberi deskripsi kegiatan pembelajaran keterampilan bahasa Inggris, } \\
\text { guru dapat menentukan pilihan teknologi informasi dan komunikasi } \\
\text { yang sesuai }\end{array}$ & 45,40 \\
\hline 13. & $\begin{array}{l}\text { Ditanyakan aspek-aspek yang perlu dievaluasi dalam suatu kegiatan } \\
\text { pembelajaran (misalnya Group Discussion), guru dapat menentukan } \\
\text { aspek-aspek proses yang penting untuk dinilai }\end{array}$ & 46,05 \\
\hline 14. & $\begin{array}{l}\text { Diberi pertanyaan tentang siklus rancangan pembelajaran, guru dapat } \\
\text { menentukan pilihan langkah-langkah rancangan pembelajaran }\end{array}$ & 46,98 \\
\hline 15. & $\begin{array}{l}\text { Diberi ciri-ciri teori belajar tertentu dalam pembelajaran bahasa } \\
\text { Inggris, guru dapat menentukan teori belajar yang dimaksud }\end{array}$ & 55,91 \\
\hline
\end{tabular}




\begin{tabular}{|c|c|c|}
\hline No. & Indikator & $\begin{array}{l}\% \\
\text { yang jawab } \\
\text { benar }\end{array}$ \\
\hline 16. & $\begin{array}{l}\text { Diberi paparan data hasil penilaian proses dan hasil pembelajaran } \\
\text { bahasa Inggris, guru dapat menentukan manfaat paparan untuk } \\
\text { menentukan tujuan tertentu }\end{array}$ & 56,51 \\
\hline 17. & $\begin{array}{l}\text { Diberi jenis karakteristik peserta didik dalam pembelajaran (bahasa } \\
\text { Inggris), guru dapat mengidentifikasikannya dengan benar }\end{array}$ & 61,07 \\
\hline 18. & $\begin{array}{l}\text { Diberikan deskripsi karakteristik pembelajaran bahasa Inggris, guru } \\
\text { dapat menentukan pilihan media yang tepat sesuai dengan materi atau } \\
\text { topik yang menjadi pokok bahasan }\end{array}$ & 67,44 \\
\hline 19. & $\begin{array}{l}\text { Diberi pertanyaan tentang prinsip pengembangan kurikulum, guru } \\
\text { dapat menentukan pilihan yang bukan termasuk prinsip-prinsip } \\
\text { pengembangan kurikulum }\end{array}$ & 70,78 \\
\hline 20. & $\begin{array}{l}\text { Diberi suatu kasus pembelajaran bahasa Inggris, guru dapat } \\
\text { menentukan keputusan transaksional yang tepat sesuai dengan } \\
\text { masalahnya }\end{array}$ & 73,00 \\
\hline 21. & $\begin{array}{l}\text { Diberi suatu rumusan indikator pencapaian suatu KD pembelajaran } \\
\text { bahasa Inggris tertentu, guru dapat menentukan rumusan tujuan } \\
\text { pembelajaran yang sesuai. }\end{array}$ & 77,83 \\
\hline 22. & $\begin{array}{l}\text { Diberi deskripsi suatu situasi pembelajaran bahasa Inggris tertentu, } \\
\text { guru dapat menentukan pilihan ungkapan (classroom language) yang } \\
\text { efektif, empatik, dan santun yang sesuai dengan situasi pembelajaran } \\
\text { tersebut. }\end{array}$ & 78,62 \\
\hline 23. & $\begin{array}{l}\text { Diberi deskripsi suatu situasi pembelajaran bahasa Inggris tertentu, } \\
\text { guru dapat menentukan pilihan ungkapan bahasa yang santun dan } \\
\text { empatik. }\end{array}$ & 79,39 \\
\hline 24. & $\begin{array}{l}\text { Diberi suatu rumusan tujuan dan pengalaman belajar bahasa Inggris } \\
\text { tertentu, guru dapat menentukan materi pembelajaran yang sesuai. }\end{array}$ & 79,74 \\
\hline
\end{tabular}

Berdasarkan acuan yang digunakan yaitu bahwa suatu pertanyaan terkait suatu indikator dinyatakan dikuasai oleh peserta ujian jika pertanyaan tersebut dijawab benar oleh minimal 75 persen peserta, maka dari tabel di atas terlihat bahwa untuk kompetensi pedagogik baru 4 dari 24 indikator pedagogik atau hanya 17 persen yang dikuasai oleh guru Bahasa Inggris SMP. Ini berarti sebagian besar ( 83 persen) indikator pedagogik belum dikuasai oleh guru. Empat dari duapuluh empat indikator pedagogik yang sudah dikuasai guru tersebut adalah: (i) diberi suatu rumusan indikator pencapaian suatu Kompetensi Dasar (KD) pembelajaran bahasa Inggris tertentu, guru dapat menentukan rumusan tujuan pembelajaran yang sesuai, (ii) diberi deskripsi suatu situasi pembelajaran bahasa Inggris tertentu, guru dapat menentukan pilihan ungkapan (classroom language) yang efektif, empatik, dan santun yang sesuai dengan situasi pembelajaran tersebut, (iii) diberi deskripsi suatu situasi pembelajaran bahasa Inggris tertentu, guru dapat menentukan pilihan ungkapan bahasa yang santun dan empatik, 
dan (iv) diberi suatu rumusan tujuan dan pengalaman belajar bahasa Inggris tertentu, guru dapat menentukan materi pembelajaran yang sesuai.

Selanjutnya untuk indikator pedagogik yang paling jelek pencapaiannya oleh guru terdiri atas tiga indikator. Pencapaian yang sangat tidak memuaskan ini karena persentese guru yang menjawab benar atas pertanyaan terkait indikator tersebut masih di bawah 20 persen. Indikator-indikator ini sengaja disebutkan berikut ini agar menjadi perhatian khusus ketika diadakan pelatihan untuk meningkatkan kompetensi pedagogik. Ketiga indikator itu adalah: (i) diberi suatu topik pembelajaran bahasa Inggris untuk pembelajaran teks tertentu, guru dapat menentukan bekal-ajar awal yang diperlukan peserta didik, (ii) diberi deskripsi kasus dalam suatu pembelajaran bahasa Inggris, guru dapat menentukan rumusan judul PTK yang paling sesuai, dan (iii) diberi contoh tulisan siswa yang mengandung kesalahan tertentu, guru dapat menentukan kesulitan peserta didik dalam mempelajari keterampilan berbahasa Inggris.

Tabel E.3. Penguasaan Guru Bahasa Inggris SMP terhadap setiap Indikator kompetensi profesional dalam UKG 2012 (N=13.406)

\begin{tabular}{|l|l|c|}
\hline No. & \multicolumn{1}{|c|}{ Indikator } & $\begin{array}{c}\text { \% } \\
\text { yang jawab } \\
\text { benar }\end{array}$ \\
\hline 1. & $\begin{array}{l}\text { Diberi sebuah teks rumpang, guru dapat melengkapi teks tersebut } \\
\text { dengan detail kalimat predictive yang tepat }\end{array}$ & 14,76 \\
\hline 2. & $\begin{array}{l}\text { Diberi sebuah teks, guru dapat menentukan definisi kata dalam teks } \\
\text { tersebut }\end{array}$ & 16,16 \\
\hline 3. & $\begin{array}{l}\text { Diberi beberapa kalimat acak, guru dapat menyusun kalimat-kalimat } \\
\text { acak tersebut menjadi paragraf yang padu dan logis }\end{array}$ & 16,94 \\
\hline 4. & $\begin{array}{l}\text { Diberi teks tertulis fungsional pendek berbentuk letter guru dapat } \\
\text { menentukan: gambaran umum }\end{array}$ & 22,89 \\
\hline 5. & $\begin{array}{l}\text { Diberi sebuah teks rumpang, guru dapat melengkapi teks tersebut } \\
\text { dengan kata determinatives yang tepat }\end{array}$ & 23,85 \\
\hline 6. & $\begin{array}{l}\text { Diberi teks tertulis fungsional berbentuk procedure, guru dapat } \\
\text { menentukan informasi tersirat }\end{array}$ & 28,76 \\
\hline 7. & $\begin{array}{l}\text { Diberi teks tertulis fungsional pendek berbentuk advertisement/ } \\
\text { brochure, guru dapat menentukan makna kata }\end{array}$ & 29,37 \\
\hline 8. & $\begin{array}{l}\text { Diberi sebuah teks rumpang, guru dapat melengkapi teks tersebut } \\
\text { dengan kata conjunction yang tepat }\end{array}$ & 33,05 \\
\hline 9. & Gaya penuangan cerita & 34,98 \\
\hline 10. & $\begin{array}{l}\text { Diberi sebuah teks rumpang, guru dapat melengkapi teks tersebut } \\
\text { dengan kata preposition yang tepat }\end{array}$ & 36,48 \\
\hline 11. & $\begin{array}{l}\text { d.Diberi teks tertulis fungsional berbentuk report, guru dapat } \\
\text { menentuka informasi rinci }\end{array}$ & 38,75 \\
\hline 12. & Makna kata & $\begin{array}{l}\text { Diberi sebuah teks, guru dapat menentukan makna antonim kata dalam } \\
\text { teks tersebut }\end{array}$ \\
\hline 13,03 \\
\hline
\end{tabular}




\begin{tabular}{|c|c|c|}
\hline No. & Indikator & $\begin{array}{l}\% \\
\text { yang jawab } \\
\text { benar }\end{array}$ \\
\hline 14. & $\begin{array}{l}\text { Diberi beberapa kata acak, guru dapat menyusun kata-kata acak } \\
\text { tersebut menjadi kalimat yang benar dan logis }\end{array}$ & 42,72 \\
\hline 15. & $\begin{array}{l}\text { Diberi teks tertulis fungsional berbentuk procedure, guru dapat } \\
\text { menentukan: informasi spesifik }\end{array}$ & 43,94 \\
\hline 16. & $\begin{array}{l}\text { Diberi teks tertulis fungsional berbentuk report, guru dapat menentuka } \\
\text { tujuan komunikatif }\end{array}$ & 44,01 \\
\hline 17. & $\begin{array}{l}\text { Diberi teks tertulis fungsional pendek berbentuk announcement, guru } \\
\text { dapat menentukan informasi rinci tersirat }\end{array}$ & 44,83 \\
\hline 18. & $\begin{array}{l}\text { Diberi teks tertulis fungsional berbentuk narrative, guru dapat } \\
\text { menentukan pesan moral }\end{array}$ & 46,63 \\
\hline 19. & $\begin{array}{l}\text { Diberi sebuah teks, guru dapat menentukan makna kontekstual kata } \\
\text { dalam teks tersebut }\end{array}$ & 49,13 \\
\hline 20. & $\begin{array}{l}\text { Diberi beberapa kalimat dengan tanda baca dan ejaan yang salah, guru } \\
\text { dapat menentukan satu kalimat yang menggunakan tanda baca dan } \\
\text { ejaan yang benar }\end{array}$ & 49,91 \\
\hline 21. & $\begin{array}{l}\text { Diberi teks tertulis fungsional pendek berbentuk letter guru dapat } \\
\text { menentukan: gaya penulisan surat }\end{array}$ & 51,94 \\
\hline 22. & $\begin{array}{l}\text { Diberi teks tertulis fungsional berbentuk report, guru dapat menentuka } \\
\text { informasi tertentu }\end{array}$ & 54,80 \\
\hline 23. & $\begin{array}{l}\text { Diberi sebuah teks rumpang, guru dapat melengkapi teks tersebut } \\
\text { dengan kalimat main idea yang tepat }\end{array}$ & 58,28 \\
\hline 24. & $\begin{array}{l}\text { Diberi teks tertulis fungsional berbentuk report, guru dapat menentuka } \\
\text { gambaran umum }\end{array}$ & 60,70 \\
\hline 25. & $\begin{array}{l}\text { Diberi teks tertulis fungsional pendek berbentuk advertisement/ } \\
\text { brochure, guru dapat menentukan informasi tertentu }\end{array}$ & 61,26 \\
\hline 26. & $\begin{array}{l}\text { Diberi teks tertulis fungsional berbentuk recount, guru dapat } \\
\text { menentukan pikiran utama }\end{array}$ & 62,75 \\
\hline 27. & $\begin{array}{l}\text { Diberi sebuah teks, guru dapat menentukan makna sinonim kata dalam } \\
\text { teks tersebut }\end{array}$ & 62,89 \\
\hline 28. & $\begin{array}{l}\text { Diberi sebuah teks rumpang, guru dapat melengkapi teks tersebut } \\
\text { dengan detail kalimat elaborative supporting yang tepat }\end{array}$ & 63,54 \\
\hline 29. & $\begin{array}{l}\text { Diberi teks tertulis fungsional pendek berbentuk announcement, guru } \\
\text { dapat menentukan makna kata }\end{array}$ & 64,34 \\
\hline 30. & $\begin{array}{l}\text { Diberi teks tertulis fungsional pendek berbentuk letter guru dapat } \\
\text { menentukan: tujuan komunikatif teks tersebut }\end{array}$ & 65,79 \\
\hline 31. & $\begin{array}{l}\text { Diberi teks tertulis fungsional pendek berbentuk announcement, guru } \\
\text { dapat menentukan informasi tertentu }\end{array}$ & 66,84 \\
\hline 32. & $\begin{array}{l}\text { Diberi teks tertulis fungsional pendek yang menyertai grafik, guru } \\
\text { dapat menentuka informasi rinci tersirat }\end{array}$ & 67,40 \\
\hline 33. & $\begin{array}{l}\text { Diberi teks tertulis fungsional berbentuk narrative, guru dapat } \\
\text { menentukan informasi tersirat }\end{array}$ & 67,47 \\
\hline 34. & $\begin{array}{l}\text { Diberi sebuah teks rumpang, guru dapat melengkapi teks tersebut } \\
\text { dengan kata connectors yang tepat }\end{array}$ & 67,51 \\
\hline
\end{tabular}




\begin{tabular}{|c|c|c|}
\hline No. & Indikator & $\begin{array}{c}\% \\
\text { yang jawab } \\
\text { benar }\end{array}$ \\
\hline 35. & $\begin{array}{l}\text { Diberi teks tertulis fungsional pendek berbentuk letter guru dapat } \\
\text { menentukan makna kata }\end{array}$ & 68,23 \\
\hline 36. & $\begin{array}{l}\text { Diberi teks tertulis fungsional berbentuk recount, guru dapat } \\
\text { menentukan gambaran umum }\end{array}$ & 69,36 \\
\hline 37. & $\begin{array}{l}\text { Diberi teks tertulis fungsional berbentuk narrative, guru dapat } \\
\text { menentukan rujukan kata }\end{array}$ & 71,00 \\
\hline 38. & $\begin{array}{l}\text { Diberi teks tertulis fungsional berbentuk recount, guru dapat } \\
\text { menentukan makna kata }\end{array}$ & 71,12 \\
\hline 39. & $\begin{array}{l}\text { Diberi teks tertulis fungsional pendek yang menyertai grafik, guru } \\
\text { dapat menentuka gambaran umum }\end{array}$ & 72,31 \\
\hline 40. & $\begin{array}{l}\text { Diberi teks tertulis fungsional berbentuk narrative, guru dapat } \\
\text { menentukan pikiran utama paragraf tertentu }\end{array}$ & 73,91 \\
\hline 41. & Informasi rinci tersurat & 75,51 \\
\hline 42. & $\begin{array}{l}\text { Diberi teks tertulis fungsional pendek berbentuk advertisement/ } \\
\text { brochure, guru dapat menentukan: gambaran umum }\end{array}$ & 76,11 \\
\hline 43. & $\begin{array}{l}\text { Diberi teks tertulis fungsional berbentuk narrative, guru dapat } \\
\text { menentukan tujuan komunikatif }\end{array}$ & 76,30 \\
\hline 44. & $\begin{array}{l}\text { Diberi teks tertulis fungsional pendek berbentuk letter guru dapat } \\
\text { menentukan: informasi tertentu }\end{array}$ & 77,08 \\
\hline 45. & $\begin{array}{l}\text { Diberi teks tertulis fungsional berbentuk narrative, guru dapat } \\
\text { menentukan informasi tertentu }\end{array}$ & 77,63 \\
\hline 46. & $\begin{array}{l}\text { Diberi teks tertulis fungsional pendek berbentuk announcement, guru } \\
\text { dapat menentukan gambaran umum }\end{array}$ & 78,11 \\
\hline 47. & $\begin{array}{l}\text { Diberi teks tertulis fungsional pendek berbentuk advertisement/ } \\
\text { brochure, guru dapat menentukan tujuan komunikatif dari teks }\end{array}$ & 78,50 \\
\hline 48. & $\begin{array}{l}\text { Diberi teks tertulis fungsional pendek yang menyertai grafik, guru } \\
\text { dapat menentuka informasi tertentu }\end{array}$ & 79,76 \\
\hline 49. & $\begin{array}{l}\text { Diberi teks tertulis fungsional berbentuk recount, guru dapat } \\
\text { menentukan informasi tersirat }\end{array}$ & 81,77 \\
\hline 50. & $\begin{array}{l}\text { Diberi teks tertulis fungsional berbentuk procedure, guru dapat } \\
\text { menentukan rujukan kata }\end{array}$ & 82,46 \\
\hline 51. & $\begin{array}{l}\text { Diberi teks tertulis fungsional berbentuk recount, guru dapat } \\
\text { menentukan informasi tertentu }\end{array}$ & 83,75 \\
\hline 52. & $\begin{array}{l}\text { Diberi sebuah teks rumpang, guru dapat melengkapi teks tersebut } \\
\text { dengan kata verb forms yang tepat }\end{array}$ & 83,91 \\
\hline 53. & $\begin{array}{l}\text { Diberi teks tertulis fungsional berbentuk recount, guru dapat } \\
\text { menentukan informasi rinci tersurat }\end{array}$ & 86,19 \\
\hline 54. & $\begin{array}{l}\text { Diberi teks tertulis fungsional berbentuk narrative, guru dapat } \\
\text { menentukan gambaran umum }\end{array}$ & 86,93 \\
\hline 55. & $\begin{array}{l}\text { Diberi sebuah teks, guru dapat menentukan makna konotasi kata } \\
\text { dalam teks tersebut }\end{array}$ & 88,65 \\
\hline
\end{tabular}




\begin{tabular}{|l|l|c|}
\hline No. & \multicolumn{1}{|c|}{ Indikator } & $\begin{array}{c}\% \\
\text { yang jawab } \\
\text { benar }\end{array}$ \\
\hline 56. & $\begin{array}{l}\text { Diberi situasi penggunaan bahasa tertentu, guru dapat menentukan } \\
\text { penggunaan ragam bahasa dengan kepantasan, kesopanan, dan atau } \\
\text { ragam fomal/ informal }\end{array}$ & 89,09 \\
\hline 57. & $\begin{array}{l}\text { Diberi teks tertulis fungsional berbentuk procedure, guru dapat } \\
\text { menentukan gambaran umum }\end{array}$ & 89,80 \\
\hline 58. & $\begin{array}{l}\text { Diberi sebuah teks, guru dapat menentukan makna denotasi kata dalam } \\
\text { teks tersebut }\end{array}$ & 90,17 \\
\hline 59. & Gambaran umum & 91,18 \\
\hline
\end{tabular}

Berdasarkan acuan yang sama yaitu bahwa suatu pertanyaan terkait suatu indikator dinyatakan dikuasai oleh peserta ujian jika pertanyaan tersebut dijawab benar oleh minimal 75 persen peserta, maka dari tabel di atas terlihat bahwa untuk kompetensi profesional terdapat 19 dari 59 indikator profesional atau 32 persen yang sudah dikuasai oleh guru Bahasa Inggris. Ini berarti sebagian besar ( 68 persen) indikator profesional masih belum dikuasai oleh guru juga. Kesembilanbelas indikator profesional yang sudah dikuasai guru tersebut adalah: (i) informasi rinci tersurat, (ii) diberi teks tertulis fungsional pendek berbentuk advertisement/brochure, guru dapat menentukan: gambaran umum, (iii) diberi teks tertulis fungsional berbentuk narrative, guru dapat menentukan tujuan komunikatif, (iv) diberi teks tertulis fungsional pendek berbentuk letter guru dapat menentukan: informasi tertentu, (v) diberi teks tertulis fungsional berbentuk narrative, guru dapat menentukan informasi tertentu, (vi) diberi teks tertulis fungsional pendek berbentuk announcement, guru dapat menentukan gambaran umum, (vii) diberi teks tertulis fungsional pendek berbentuk advertisement/ brochure, guru dapat menentukan tujuan komunikatif dari teks, (viii) diberi teks tertulis fungsional pendek yang menyertai grafik, guru dapat menentuka informasi tertentu, (ix) diberi teks tertulis fungsional berbentuk recount, guru dapat menentukan informasi tersirat, (x) diberi teks tertulis fungsional berbentuk procedure, guru dapat menentukan rujukan kata, (xi) diberi teks tertulis fungsional berbentuk recount, guru dapat menentukan informasi tertentu, (xii) diberi sebuah teks rumpang, guru dapat melengkapi teks tersebut dengan kata verb forms yang tepat, (xiii) diberi teks tertulis fungsional berbentuk recount, guru dapat menentukan informasi rinci tersurat, (xiv) diberi teks tertulis fungsional berbentuk narrative, guru dapat menentukan gambaran umum, (xv) diberi sebuah teks, guru dapat menentukan makna konotasi kata dalam teks tersebut, (xvi) diberi situasi penggunaan bahasa tertentu, guru dapat menentukan penggunaan ragam bahasa dengan kepantasan, kesopanan, dan atau ragam fomal/informal, (xvii) diberi teks tertulis fungsional berbentuk procedure, guru dapat menentukan gambaran umum, (xviii) diberi sebuah teks, guru dapat menentukan makna denotasi kata dalam teks tersebut dan (xix) gambaran umum. 
Selanjutnya untuk indikator profesional yang paling jelek pencapaiannya oleh guru terdiri atas tiga indikator. Pencapaian yang sangat tidak memuaskan ini karena persentese guru yang menjawab benar atas pertanyaan terkait indikator tersebut masih di bawah 20 persen. Indikator-indikator ini sengaja disebutkan berikut ini agar menjadi perhatian khusus ketika diadakan pelatihan untuk meningkatkan kompetensi profesional. Ketiga indikator itu adalah: (i) diberi sebuah teks rumpang, guru dapat melengkapi teks tersebut dengan detail kalimat predictive yang tepat, (ii) diberi sebuah teks, guru dapat menentukan definisi kata dalam teks tersebut dan (iii) diberi beberapa kalimat acak, guru dapat menyusun kalimat-kalimat acak tersebut menjadi paragraf yang padu dan logis.

Oleh karena sebagian besar guru Bahasa Inggris belum menguasai indikator penentu kompetensi baik pedagogik maupun profesional ini maka akan cukup sulit bagi pemerintah untuk mengharapkan agar guruguru Bahasa Inggris dapat dengan mudah menerima adanya perubahan peningkatan mutu melalui perubahan kurikulum yaitu dari Kurikulum 2006 menjadi Kurikulum 2013 (K-13) dan mengimplementasikannya. Langkah pertama yang harus dilakukan pemerintah sebelum meminta guru Bahasa Inggris untuk mengimplementasikan K-13 adalah menyusun program pendidikan dan pelatihan untuk meningkatkan kompetensi guru terlebih dahulu agar guruguru menjadi lebih siap untuk menerima perubahan kurikulum dan berupaya untuk mengimplementasikannya. Pelatihan tersebut agar terfokus pada indikator-indikator kompetensi baik pedagogik maupun profesional yang pencapaiannya masih belum maksimal.

\section{SIMPULAN DAN SARAN}

\section{Simpulan}

Dengan menggunakan Penilaian Acuan Norma (PAN) bahwa seorang peserta didik dinyatakan lulus jika nilainya minimal 60 dalam skala 100, maka sebagian besar guru Bahasa Inggris tidak lulus UKG karena rerata nilai akhir UKG adalah 56,84, masih di bawah ketentuan PAN yaitu minimal 60 dalam skala 100.

Selanjutnya, dengan mengacu pada kriteria penguasaan indikator yaitu minimal 75 persen peserta ujian menjawab benar untuk indikator tertentu; maka untuk indikator kompetensi pedagogik hanya 4 dari 24 indikator atau hanya 17 persen penentu kompetensi pedagogik yang dikuasai guru, sisanya sebanyak 83 persen indikator belum dikuasai oleh guru. Sedangkan untuk indikator profesional penguasaan guru Bahasa Inggris terhadap indikator penentunya memang sedikit lebih tinggi yaitu sebanyak 32 persen indikator, namun angka ini pun masih terlalu kecil, karena sebanyak 68 pesen indikator profesional belum dikuasai oleh guru.

Dengan demikian, secara umum disimpulkan bahwa kompetensi guru Bahasa Inggris SMP baik pedagogik dan profesional masih rendah sehingga tidak akan mudah bagi guru-guruBahasaInggris SMPuntukmenerima perubahan kebijakan peningkatan mutu pendidikan dan mengimplementasikannya. Dengan kompetensi guru yang ada sulit bagi guru untuk menerima perubahan kebijakan peningkatan mutu pendidikan melalui perubahan dari kurilukum 2006 ke kurikulum K-13. 
Saran

Berdasarkan simpulan dari kajian ini disusun saran-saran kebijakan berikut:

Pemerintah dalam hal ini Kemendikbud atau lebih khusus lagi Direktorat Jenderal Guru dan Tenaga Kependidikan (Ditjen GTK) harus terus berupaya mengadakan pelatihan untuk meningkatkan kompetensi pedagogik dan profesional guru Bahasa Inggris SMP sebelum melakukan pelatihan kurikulum K13 karena rata-rata nilai UKG-2012 guru Bahasa Inggris SMP masih lebih rendah jika dibandingkan dengan acuan yang ditetapkan yaitu PAN 60 dalam skala 100. Rata-rata nilai UKG tahun 2012 guru Bahasa Inggris SMP baru mencapai 56,84. Karena rerata nilai yang rendah tersebut maka seluruh guru yang nilai reratanya di bawah 60 , yaitu acuan kelulusan yang digunakan agar perlu dilatih lagi dengan materi kompetensi pedagogik dan profesional.
Selanjutnya dengan mengacu pada kriteria pengusaan materi maka pelatihan peningkatan kompetensi guru Bahasa Inggris SMP tersebut agar lebih difokuskan pada kompetensi pedagogik karena baru sekitar 17 persen indikator penentu kompetensi pedagogik yang dikuasai guru, sedangkan untuk indikator penentu kompetensi profesional hasilnya sedikit lebih baik karena sebanyak 32 persen indikator sudah dikuasai oleh guru. Untuk menfokuskan materi pelatihan maka pelatihan agar mengacu pada tabel penguasaan indikator-indikator yang belum mencapai kriteria yang ditetapkan sebagaimana disajikan dalam Tabel E.2, dan E.3. Kriteria yang ditetapkan adalah bahwa suatu indicator dikatakan belum dikuasai guru apabila pertanyaan terkait indikator kompetensi tersebut belum dijawab dengan benar oleh 75 persen peserta ujian.

\section{PUSTAKA ACUAN}

Badan Pengembangan Sumber Daya Manusia Pendidikan dan Kebudayaan dan Penjaminan Mutu Pendidikan (BPSDMPK dan PMP), 2012. Pedoman Uji Kompetensi Guru (UKG) 2012.

Badan Standar Nasional Pendidikan (BSNP), 2006. Panduan Penyusunan Kurikulum Tingkat Satuan Pendidikan Jenjang Pendidikan Dasar dan Menengah.

Direktorat Jenderal Guru dan Tenaga Kependidikan (Ditjen GTK). 2012. Data Nilai UKG 2012.

Ciptasari R.N. 2009. Kompetensi Profesional Guru Pendidikan Agama Islam Kelas XII di SMA Kolombo Sleman Yogyakarta. Skripsi. Yogyakarta: Jurusan Pendidikan Agama Islam Fakultas Tarbiyah Universitas Islam Negeri Sunan Kalijaga Yogyakarta.

Ermawati. Y. 2015. Hubungan Antara Kompetensi Guru Dengan Prestasi Belajar PAI Pada Siswa SMP Negeri 1 Tempuran Kabupaten Magelang. Skripsi. Salatiga: Jurusan Pendidikan Agama Islam Fakultas Tarbiyah Dan Ilmu Keguruan Institut Agama Islam Negeri (IAIN) Salatiga.

Jalmo, T. dan Rustaman, N. Y. 2010. Pengembangan Program Pelatihan Peningkatan Kompetensi Guru IPA SMP. Forum Kependidikan, Jurusan PMIPA FKIP Universitas Lampung dan Prodi IPA SPs Universitas Pendidikan Indonesia Volume 30, Nomor 1, Juni 2010, hlm. 79 - 88. 
Komara, E. 2016. Perlindungan Profesi Guru Di Indonesia. Mimbar Pendidikan: Jurnal Indonesia Untuk Kajian Pendidikan UPI Bandung Volume 1 Nomor 2, September 2016, hlm.151-160.

Murniyati. 2013. Peran guru sebagai pengembang kurikulum dalam peningkatan mutu pendidikan di SDN Pondok Ranggon 04 Pagi Cipayung Jakarta Timur. Skripsi. Jakarta: Jurusan Pendidikan Agama Islam Fakultas Ilmu Terbiyah dan Keguruan Universitas Islam Negeri Syarif Hidayatullah Jakarta.

Novauli F.M. 2015. Kompetensi Guru Dalam Peningkatan Prestasi Belajar Pada SMP Negeri Dalam Kota Banda Aceh. Jurnal Administrasi Pendidikan Pascasarjana Universitas Syiah Kuala Volume 3, Nomor 1, Februari 2015, hlm. 45- 67.

Ngasbun, E. 2012. Pengembangan Profesionalisme Guru Melalui Peningkatan Kompetensi Secara Komprehensif. Proceeding: Seminar Nasional "Profesionalisme Guru Dalam Perspektif Global” Tahun 2012, hlm. 23 - 30.

Patimah. 2016. Pendidik Dalam Pengembangan Kurikulum. Jurnal Al Ibtida IAIN Syekh Nurjati Cirebon, Volume 3 Nomor 1, Juni 2016, hlm. 147-161.

Peraturan Menteri Pendidikan Nasional Nomor 16 Tahun 2007 Tanggal 4 Mei 2007 Standar Kualifikasi Akademik Dan Kompetensi Guru.

Peraturan Menteri Pendidikan dan Kebudayaan (Permendikbud) Nomor 81A/2013 tentang Implementasi Kurikulum 2013.

Peraturan Pemerintah Nomor 74 Tahun 2008 tentang Guru.

Peraturan Pemerintah Nomor 19 tahun 2005 tentang Standar Nasional Pendidikan.

Qomariyah. 2014. Kesiapan Guru Dalam Menghadapi Implementasi Kurikulum 2013. Jurnal Pendidikan Ekonomi IKIP Veteran Semarang Volume 2 Nomor 1, November 2014, hlm. 21-35.

Resmaningrum, Y. H. 2015. Implementasi Kurikulum 2013 Dalam Pembelajaran Bahasa Indonesia Di SMPN 4 Kalasan. Skripsi. Yogyakarta: Program Studi Pendidikan Bahasa Dan Sastra Indonesia Fakultas Bahasa Dan Seni Universitas Negeri Yogyakarta.

Rizal. 2012. Hasil Ujian Kompetensi Guru Rendah dalam http://poskotanews.com/2012/03/16/ hasil-ujian-kompetensi-guru-rendah, diunduh pada diunduh pada 25 Februari 2016.

Sarwanto. 2012. Refleksi Uji Kompetensi Guru IPA Tahun 2012. Prosiding: Seminar Nasional Fisika dan Pendidikan Fisika Volume 1, Nomor 4, tahun 2012, hlm. 395-401.

Slameto. 2010. Belajar dan Faktor-Faktor yang Mempengaruhinya. Jakarta: PT Rineka Cipta.

Suharso, Y. 2013. Peran dan Tanggungjawab Guru Sebagai Tenaga Profesional. Majalah Ilmiah Pawiyatan IKIP Veteran Semarang Volume XX, Nomor 4, Oktober 2013, hlm. 112-123.

Surat Keputusan (SK) Pemberhentian Pelaksanaan Kurikulum 2013 Nomor: 179342/MPK/ KR/2014 tertanggal 5 Desember 2014.

Syahbani, N. 2013. Profesionalisme Guru Dan Hasil Sertifikasi Guru Dalam Jabatan. Jurnal Al-'Ulum Volume 2, Tahun 2013, hlm. 84-94.

Undang-undang Republik Indonesia No. 14 tahun 2005 tentang Guru dan Dosen. 
Undang-undang RI No. 20 Tahun 2003 tentang Sistem Pendidikan Nasional.

Wibowo F. 2015. Kesiapan Sekolah Dalam Melaksanakan Kurikulum 2013 Di SMA Negeri 4 Kota Tegal. Skripsi. Semarang: Jurusan Kurikulum Dan Teknologi Pendidikan Program Studi Teknologi Pendidikan Fakultas Ilmu Pendidikan Universitas Negeri Semarang.

Yama, S. F. 2015. Pengaruh Pelatihan Guru, Kompetensi Guru Dan Pemanfaatan Sarana Prasarana Terhadap Kesiapan Guru Prodi Bisnis Manajemen Dalam Implementasi Kurikulum 2013 SMK N 1 Purbalingga Tahun Ajaran 2014/2015. Skripsi. Semarang: Jurusan Pendidikan Ekonomi Fakultas Ekonomi Universitas Negeri Semarang. 